\title{
SHEEP BEDDING IN THE CENTENNIAL MOUNTAINS OF MONTANA AND IDAHO: EFFECTS ON VEGETATION
}

\author{
Steven. S. Seefeldt ${ }^{1}$ and April B. Leytem ${ }^{2}$
}

\begin{abstract}
In summer, bands of sheep are grazed in western North American mountains. At night the sheep are concentrated into bedding areas. In the study area, each bedding area is only utilized by sheep for one night a year for 2 out of 3 years. Vegetation in the bedding areas was compared to vegetation outside these areas. Both perennial forb cover and total perennial cover were greater outside $(48 \%$ and $61 \%$, respectively) than inside (29\% and $36 \%$, respectively) the bedding areas. Annual forb cover one year after sheep grazing was greater inside (17\%) bedding areas than outside (5\%). Immediately after sheep bedding, total forb cover was greater outside the bedding areas. Forb and grass biomass were greater outside the bedding areas compared to inside. Total vegetation biomass outside $\left(240 \mathrm{~g} \cdot \mathrm{m}^{-2}\right)$ the bedding areas was more than double the amount inside $\left(86 \mathrm{~g} \cdot \mathrm{m}^{-2}\right)$ immediately after bedding. In the year after bedding, vegetation biomass inside the bedding areas increased, but was still less than outside. Sheep bedding areas were not invaded by nonnative plants. Sheep bedding reduced vegetation quantity and changed relative abundance of annual forbs. Vegetation in the bedding areas was resilient to grazing impacts, and long-term use of sites in this ecosystem does not significantly degrade vegetation.
\end{abstract}

Resumen._En el verano, se pastorean manadas de ovejas en las montañas de Norteamérica. De noche se concentran en ciertas áreas de reposo. En el área de estudio, las ovejas sólo utilizan estos lugares 1 día al año en 2 de cada 3 años. Comparamos la vegetación en estas áreas de reposo con la vegetación fuera de ellas. La cobertura de plantas herbáceas perennes y la cobertura total de plantas perennes fueron mayores afuera (48\% y $61 \%$, respectivamente) que adentro (29\% y 36\%, respectivamente) de las áreas de reposo. La cobertura de plantas herbáceas anuales un año después del pastoreo de ovejas fue mayor adentro (17\%) de estas áreas de reposo que afuera $(5 \%)$. Inmediatamente después de que las ovejas habían dormido en determinados lugares, la cobertura total de plantas herbáceas fue mayor fuera de estas áreas. La biomasa de plantas herbáceas y gramíneas fue mayor fuera de estas áreas que dentro de ellas. La biomasa total de vegetación fuera de las áreas donde duermen $\left(240 \mathrm{~g} \cdot \mathrm{m}^{-2}\right)$ fue más del doble de la biomasa total dentro de ellas $\left(86 \mathrm{~g} \cdot \mathrm{m}^{-2}\right)$, inmediatamente después de que durmieron allí. El año después que durmieron en estas áreas, aumentó la biomasa de vegetación dentro de ellas, pero aún así fue menor que afuera. Las áreas de reposo de las ovejas no se vieron invadidas por plantas exóticas, pero en ellas se vio reducida la cantidad de vegetación y se cambió la abundancia relativa de plantas herbáceas anuales. La vegetación en estas áreas se mostró resistente al impacto del pastoreo, y el uso a largo plazo de sitios en este ecosistema no está degradando la vegetación de forma apreciable.

Sheep and lamb production is an important industry in the state of Idaho, as it is in other states and provinces in North America. During summer months in western North America, many bands of sheep are grazed in the mountains. Sheep bands generally contain 1000 ewes with over 1000 lambs, and they are accompanied by a shepherd with a horse and dogs to move and protect them. At night the sheep are concentrated in an area typically less than 0.5 ha to guard them from theft and predation. Bedding on high ground in concentrated groups is also part of their natural behavior (Bowns 1971). These sheep bedding areas are often located on open sites with shallow soils and few, if any, trees or shrubs (Knight
1994). Many of these sites are considered historic in that they have been bedded on for up to a century. Consequently, vegetation adaptation to increased nutrients, utilization, and trampling may have occurred.

There have been no published studies in North America concerning the impact of sheep bedding areas on vegetation diversity and vegetative biomass. However, as part of this research project, inputs of sheep bedding on soil nutrients have been determined; specifically, $\mathrm{NO}_{3}-\mathrm{N}, \mathrm{NH}_{4}-\mathrm{N}$, and total soluble nitrogen increase after bedding and then decrease to background levels after the following winter (Leytem and Seefeldt 2008). Additionally, there was a reduction in total carbon, nitrogen, and

${ }^{1}$ USDA-ARS, Subarctic Agricultural Research Unit, University of Alaska Fairbanks, Room 355 O'Neill Building, Fairbanks, AK 99775. E-mail: steven.seefeldt@ars.usda.gov

2USDA Agricultural Research Service, Northwest Irrigation and Soils Research Laboratory, 3793 North 3600 East, Kimberly, ID 83341 
organic carbon and an increase in soluble phosphorous and nitrogen inside bedding areas compared with outside bedding areas. In eastern Africa, the study of bomas, which are somewhat equivalent to bedding areas, has shown that, following abandonment, bomas often support a unique plant community and potentially alter the spatial pattern of nutrient cycling within the ecosystem (Augustine 2003). In northern Kenya, old bomas contained 6-9 times more soil nitrogen and phosphorus than surrounding habitats and supported thickets of regenerating umbrella thorn (Acacia tortilis [Forssk.] Hayne; Reid and Ellis 1995). In southern Kenya, abandoned bomas were dominated by a lawn of African bermudagrass (Cynodon nlemfuensis Vanderyst) with enriched concentrations of nutrients in both soils and grasses (Stelfox 1986). In these African environments, abandoned bomas supported vegetation that is beneficial to grazing and wild animals, whereas the majority of the surrounding areas were nutrient-poor and did not support as much vegetative biomass. In the semiarid regions of the northwestern United States, the impact of sheep bedding areas on soil nutrient cycling and vegetation may or may not be similar to the bomas of eastern Africa, as these bedding areas are used for much shorter periods of time.

There have been studies documenting the impacts of sheep grazing pressure on vegetation productivity and diversity (Craddock and Forsling 1938, Ellison 1954, Bowns and Bagley 1986, Scimone et al. 2007), but these studies all involve many days of seasonal grazing at various rates of intensity over a period of years, which does not reflect the same type of usage that bedding areas receive. Because of the concentration of sheep in bedding areas, more trampling and breakage of vegetation would be expected. Earlier research conducted in the same grazing range as this study and using confined sheep determined that $14 \%-40 \%$ of vegetation loss could be due to trampling (Laycock et al. 1972).

Our hypothesis is that long-term sheep bedding areas have a different vegetation community than adjacent areas. The objectives of this study were to determine whether vegetation cover, biomass, and species composition differ between sheep bedding areas and adjacent nonbedded areas; whether time since bedding resulted in changes in vegetation composition and biomass; and whether bedding areas were susceptible to invasion by nonindigenous plant species. Understanding these impacts will assist land managers in making informed decisions concerning sheep grazing practices and the use of bedding areas on rangelands.

\section{Study AREA}

This study was conducted in August and September 2004 and in July and August 2005 in the summer range of the U.S. Sheep Experiment Station (USSES), which is located in the Centennial Mountains of Montana and Idaho (Fig. 1). Vegetation was measured on 11 longterm sheep bedding areas. Sheep used these areas for one night in 2003, 2004, and/or 2005 (Table 1). Sheep band size in this study ranged from 800 ewes with 1200 lambs to 900 ewes with 1300 lambs. All sites were on mountain ridges from $2380 \mathrm{~m}$ to $2570 \mathrm{~m}$ elevation.

The USSES summer-range grazing areas are predominantly a tall-forb community (Buchanan et al. 1972). In these higher elevation sites, the predominant tree is lodgepole pine (Pinus contorta Douglas ex Louden var. latifolia Engelm. ex S. Watson), with scattered Douglas-fir (Pseudotsuga menziesii [Mirb.] Franco var. glauca [Beissn.] Franco) and Engelmann spruce (Picea engelmannii Parry ex Engelm.). The ridge areas where sheep bedding occurs are a mixed forb and grass community. Plant species inside and outside the bedding areas are listed in the Appendix.

Precipitation averages $80 \mathrm{~cm}$ per year with more than $50 \%$ falling as snow. Summer high temperatures rarely reach $33^{\circ} \mathrm{C}$ (Anonymous 1999). The soils in this area are not wellmapped, but consist mainly of forested Agric Cryoborells, forested Typic Cryoborells, and Typic Cryorthents (Youngblood et al. 1985).

According to our conversations with staff at the USSES, all sites have been used for sheep bedding for more than 50 years. There are 3 summer grazing allotments and 2 bands of sheep using the USSES summer range. Sheep grazing management is a rest rotation with 2 summers of sheep grazing following a year of rest. Sheep grazing on these allotments occurs during July and August. This level of management is slightly less intensive than the current United States Forest Service sheep grazing permit standards for the region, which state that sheep bedding should only occur once per year on any given site (Scott McCoy, personal communication). 


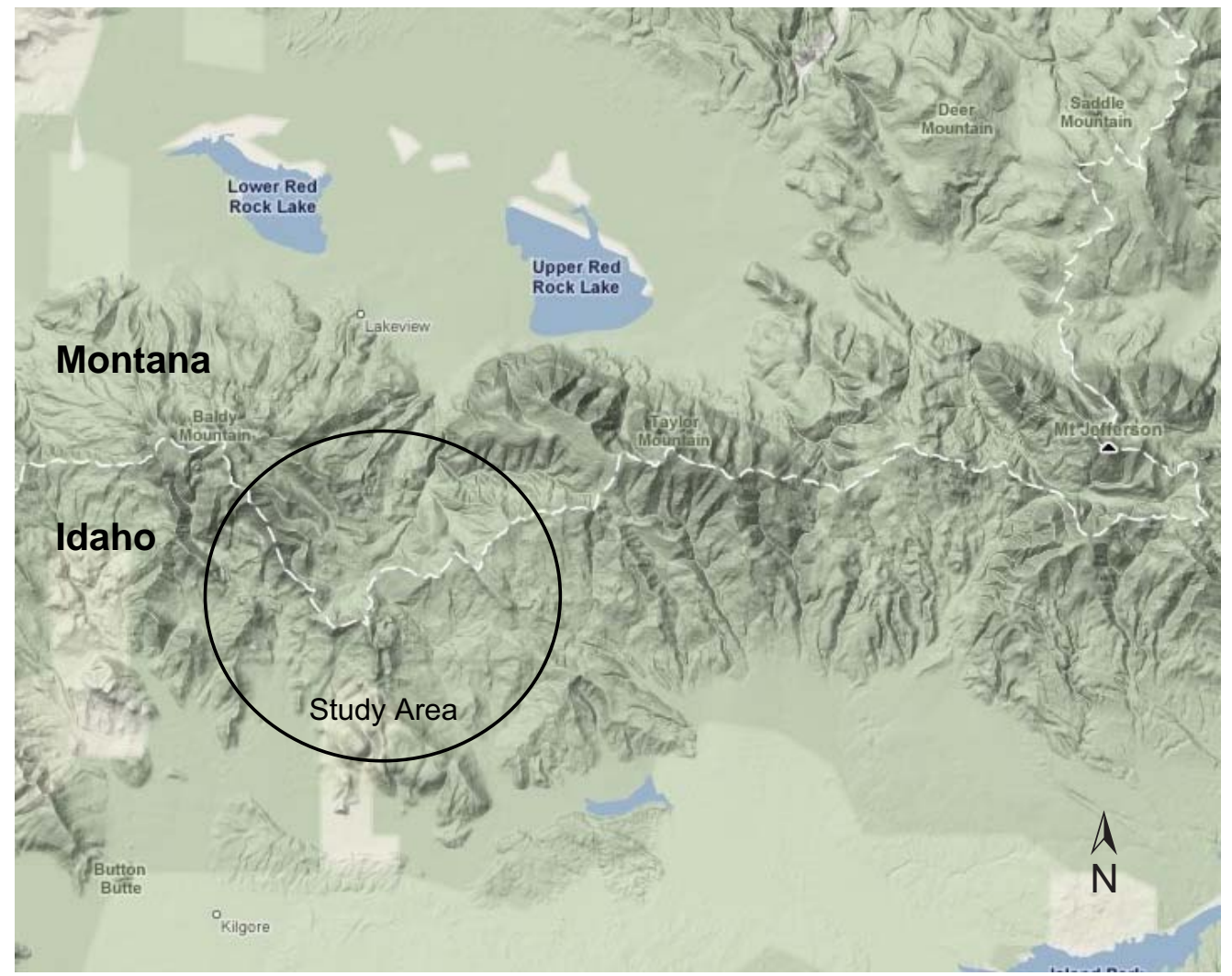

Fig. 1. Area of sheep bedding study in the Centennial Mountains of Montana and Idaho. $1 \mathrm{~cm}=3.3 \mathrm{~km}$.

TABLE 1. Sheep bedding and sampling information for sites studied in the U.S. Sheep Experiment Station summer range in the Centennial Mountains of Idaho and Montana.

\begin{tabular}{|c|c|c|c|c|c|c|}
\hline Site $^{\mathrm{a}}$ & Sheep on & Dates sampledb & $\begin{array}{l}\text { Slope } \\
(\%)\end{array}$ & Aspect & $\begin{array}{c}\text { Elevation } \\
(\mathrm{m})\end{array}$ & $\begin{array}{l}\text { Size } \\
\text { (ha) }\end{array}$ \\
\hline 2 & $2003 \& 2005$ & 19 Aug 2004 (1), 7 Jul 2005 (2), 30 Aug 2005 (0) & $6-20$ & $\mathrm{~S} \& \mathrm{SE}$ & 2399 & 0.09 \\
\hline 3 & $2003 \& 2005$ & 19 Aug $2004(1), 7$ Jul 2005 (2), 30 Aug $2005(0)$ & $0-18$ & NW \& SW & 2389 & 0.32 \\
\hline 4 & $2003 \& 2005$ & 1 Sep $2004(1), 6$ Jul 2005 (2), 30 Aug $2005(0)$ & $6-15$ & $\mathrm{E}$ & 2547 & 0.32 \\
\hline 5 & 2003 & 1 Sep 2004 (1), 6 Jul 2005 (2) & $6-15$ & NW & 2565 & 0.12 \\
\hline 6 & 2003 & 1 Sep $2004(1), 6$ Jul 2005 (2) & $5-15$ & $\mathrm{~N}$ & 2416 & 0.14 \\
\hline 7 & 2003 & 1 Sep $2004(1), 6$ Jul 2005 (2) & $6-15$ & $\mathrm{~S}$ & 2384 & 0.28 \\
\hline 8 & $2003 \& 2005$ & 1 Sep 2004 (1), 6 Jul 2005 (2), 30 Aug 2005 (0) & $6-15$ & $\mathrm{SE}$ & 2394 & 0.31 \\
\hline 9 & $2003 \& 2005$ & 1 Sep 2004 (1), 6 Jul 2005 (2), 30 Aug 2005 (0) & $5-15$ & $\mathrm{~N}$ & 2412 & 0.26 \\
\hline 10 & 2004 & 19 Aug $2004(0), 7$ Jul 2005 (1) & $0-10$ & $\mathrm{NE}$ & 2440 & 0.08 \\
\hline 13 & $2003 \& 2004$ & 2 Sep $2004(0), 7$ Jul $2005(1)$ & $4-15$ & NW & 2471 & 0.21 \\
\hline 14 & $2003 \& 2004$ & 2 Sep $2004(0), 7$ Jul $2005(1)$ & $0-15$ & SE & 2467 & 0.10 \\
\hline
\end{tabular}

a Site numbers correspond to sites in Leytem and Seefeldt (2008.

bNumber in parentheses is time (years) since sheep bedding.

\section{METHODS}

Eleven bedding sites were selected for this study based on ease of access and timing of sheep bedding. In 2004, all sites were sampled after the grazing season although not all sites were bedded on. In 2005, all sites were sampled before sheep bedding, and those sites that sheep bedded on were sampled again within 2 weeks of bedding (Table 1). Sampling conducted soon after sheep bedding was considered year 0. Sampling conducted one year 
TABLE 2. Probability of a greater $F$ test statistic for the influence of time since sheep bedding (repeated measure), location (inside and outside bedding area), and the time $\times$ location interaction on cover of plant functional types on the U.S. Sheep Experiment Station summer range in the Centennial Mountains of Idaho and Montana.

\begin{tabular}{lcccccc}
\hline & \multicolumn{3}{c}{ Source } & & \multicolumn{2}{c}{ Mean cover $(\mathrm{SE})^{\mathrm{a}}$} \\
\cline { 2 - 4 } Effect & Time & Location & Time $\times$ Location & & Inside area & Outside area \\
\hline Perennial forb & 0.762 & 0.009 & 0.82 & & $2.27(0.13)$ & $2.58(0.13)$ \\
Annual forb & 0.163 & 0.038 & 0.003 & & $1.77(0.12)$ & $1.56(0.11)$ \\
Total forb & 0.700 & 0.104 & 0.041 & & $2.63(0.06)$ & $2.70(0.06)$ \\
Perennial grass & 0.125 & 0.024 & 0.231 & & $1.09(0.10)$ & $1.38(0.12)$ \\
Total perennial & 0.482 & 0.001 & 0.146 & & $2.43(0.08)$ & $2.74(0.07)$ \\
Shrub & 0.907 & 0.994 & 0.268 & & $0.36(0.18)$ & $0.36(0.20)$ \\
\hline
\end{tabular}

${ }^{a}$ Numbers are from arcsine square-root transformed data.

after the sheep bedding event was considered year-1 sampling, and in cases where the allotment was rested for a year, a year-2 sampling occurred before the next sheep bedding event.

The perimeter of each site was mapped using a Trimble GeoXT GPS unit (Trimble Navigation Limited, Sunnyvale, CA). The perimeters of these bedding areas are distinct, with a sharp change in vegetation usually occurring within $1 \mathrm{~m}$. At each site, 3 quadrats $(30 \times 60 \mathrm{~cm})$ were randomly located inside the bedding area. Three additional quadrats were placed outside the bedding area in locations that were 10-20 m away from the perimeter but at similar elevations, aspects, and soil types. Randomization was achieved by tossing the plot frame. Data collected before bedding (years 1 and 2) included the cover for each plant species and biomass of forbs and grasses. Visual estimates of percent cover $( \pm 5 \%)$ were determined for each plant species, bare ground, litter, and rock. All plants within a quadrat were clipped at ground level, separated into forb or grass fractions, dried at $60{ }^{\circ} \mathrm{C}$ for 2 days, and weighed. Data collected 1-2 weeks after sheep bedding (year 0 ) were similar to the data collected before bedding, except that cover of plants was estimated by functional grouping (annual forb, perennial forb, perennial grass, or shrub) because species identification was not possible for most plant species.

For the analyses, the quadrat was the experimental unit $(n=48$ for year 0 and $2, n=66$ for year 1; Table 1). After an arcsine square-root transformation of cover data and a squareroot transformation of the biomass data, the distribution of model residuals did not deviate significantly from normality based on the ShapiroWilk statistic (SAS Institute, Inc., Cary, NC [2004]). The sites were up to $30 \mathrm{~km}$ from each other, resulting in differences in elevation, soils, and aspect. A randomized block design was used with site as the block. Location (inside or outside the bedding area), time since bedding, and the time $\times$ location interaction were the independent variables (fixed effects), and time since bedding was a repeated measure. Data were analyzed using MIXED procedures of SAS (SAS Institute, Inc., Cary, NC [2004]), with site as a random variable.

Annual grass was not included in the functional group analyses for cover due to its low frequency. Although cover data were collected for individual plant species before bedding, cover analyses were not conducted at the species level because assumptions of normality could not be met. The groups analyzed were perennial forb, annual forb, perennial grass, and shrub. For additional analyses, the above groups were combined into total forb and total perennial cover. Biomass functional groups for analyses were forb, grass, and total. Except for Tables 1 and 2, means and standard errors are presented in measured units, although mean separation tests were performed on transformed data. Speciesbased cover values, when combined into functional groups, increase the percent cover compared to a visual estimate of the aerial cover of the functional groups alone, because the cover values of understory plants are ignored. In a study such as this, where species succession is important, ignoring the cover of these developing plants could lead to incorrect conclusions (Lavorel et al. 2008). Additionally, the sum of species cover values in quadrats in this study rarely reaches $75 \%$, indicating that the majority of the cover was from overstory plant material.

\section{RESUlTS}

\section{Cover}

Perennial forb cover was greater outside than inside sheep bedding areas (Table 2). On 


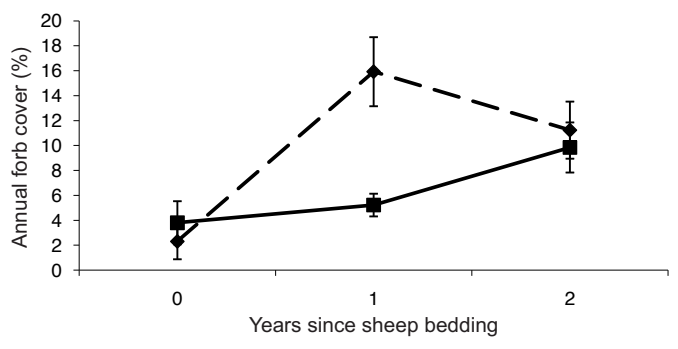

Fig. 2. Change in annual forb cover inside (dashed line) and outside (solid line) historic sheep bedding areas of the U.S. Sheep Experiment Station summer range over time. Error bars represent standard error.

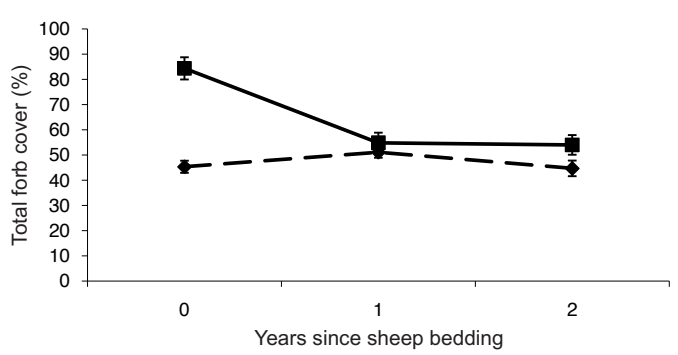

Fig. 3. Change in total forb cover inside (dashed line) and outside (solid line) historic sheep bedding areas of the U.S. Sheep Experiment Station summer range over time. Error bars represent standard error

average there was $48 \%(\mathrm{SE}=5.7)$ perennial forb cover outside compared to $29 \%$ ( $\mathrm{SE}=$ 5.7) inside.

The time $\times$ location interaction for annual forb cover was significant (Table 2, Fig. 2). Sheep consumed or trampled most of the annual forb component inside and outside the sheep bedding areas. Annual forb cover, which was measured soon after sheep bedding, decreased from about $10 \%$ to $3 \%$ (Fig. 2). At year 0 , the only 2 annual forb species found in more than one plot and both inside and outside the bedding areas were basin nemophila (Nemophila breviflora A. Gray) and Douglas' knotweed (Polygonum douglasii Greene). One year after sheep bedding, annual forb cover increased inside the bedding areas and then remained at that level in the second year; whereas, outside the bedding areas in the first and second year after bedding, annual forb cover increased slowly. The first year increase in annual forb cover inside the sheep bedding area after sheep bedding was not tied to an increase in the number of annual forb species inside the sheep bedding areas compared to outside. There were 11 annual forb species inside the bedding areas and 11 outside. The dominant annual forb species inside and outside the bedding areas one year after bedding were Douglas' knotweed and tiny trumpet (Collomia linearis Nutt.). One additional abundant annual forb species found inside, but not outside, the bedding areas was unpalatable mountain tarweed (Madia glomerata Hook.). The second year after bedding, annual forb cover inside and outside the bedding areas was similar. Three annual forb species were no longer apparent inside and 5 annual forb species were no longer apparent outside the bedding areas. However, flatspine stickseed (Lappula occidentalis [S. Watson] Greene) appeared both inside and outside the bedding areas. Tiny trumpet was the dominant annual forb species in both areas 2 years after bedding.

The time $\times$ location interaction for total forb cover was significant (Table 2, Fig. 3). Immediately after sheep bedding, total forb cover inside the bedding areas was half the amount measured outside the bedding areas. In the first and second year after bedding, the forb cover component was similar both inside and outside the bedding areas.

Perennial grass cover was greater outside $(10 \%, \mathrm{SE}=1.1)$ the bedding area compared to inside $(5 \%, \mathrm{SE}=1.6$; Table 2$)$. Total perennial cover was also greater outside bedding areas $(61 \%, \mathrm{SE}=5.0)$ compared to inside $(36 \%$, $\mathrm{SE}=5.1$; Table 2). Shrub cover was the same across time and location (Table 2), averaging $2.5 \%$.

\section{Biomass}

Forb biomass was greater outside (178 g * $\left.\mathrm{m}^{-2}, \mathrm{SE}=13\right)$ than inside $\left(112 \mathrm{~g} \cdot \mathrm{m}^{-2}, \mathrm{SE}=\right.$ 13) the sheep bedding areas (Table 3, Fig. 4). Forb biomass increased at similar rates inside and outside the bedding areas the first year after bedding and then declined at similar rates the following year. The time $\times$ location interaction for grass biomass was significant (Table 3, Fig. 5). Sheep bedding reduced grass biomass inside the sheep bedding areas to $<25 \%$ of outside biomass. A year later there was $50 \%$ less grass biomass inside, but by the second year, grass biomass was similar inside and outside the bedding area. The time $\times$ location interaction for total biomass was significant (Table 3, Fig. 6). Within 2 weeks after 
TABLE 3. Probability of a greater $F$ test statistic for the influence of time since sheep bedding (repeated measure), location (inside and outside bedding area), and the time $\times$ location interaction on biomass of plant functional types on the U.S. Sheep Experiment Station summer range in the Centennial Mountains of Idaho and Montana.

\begin{tabular}{|c|c|c|c|c|c|}
\hline \multirow[b]{2}{*}{ Effect } & \multicolumn{3}{|c|}{ Source } & \multicolumn{2}{|c|}{ Mean cover $(\mathrm{SE})^{\mathrm{a}}$} \\
\hline & Time & Location & Time $\times$ location & Inside area & Outside area \\
\hline Forb & $<0.001$ & $<0.001$ & 0.265 & $4.18(0.25)$ & $5.18(0.25)$ \\
\hline Grass & 0.044 & 0.002 & 0.042 & $1.53(0.23)$ & $2.33(0.23)$ \\
\hline Total & $<0.001$ & $<0.001$ & 0.007 & $4.59(0.20)$ & $6.07(0.20)$ \\
\hline
\end{tabular}

aNumbers are from square-root transformed data.

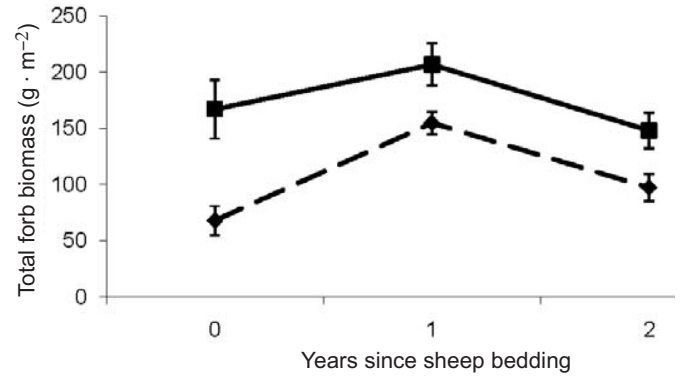

Fig. 4. Change in total forb biomass inside (dashed line) and outside (solid line) historic sheep bedding areas of the U.S. Sheep Experiment Station summer range over time. Error bars represent standard error.

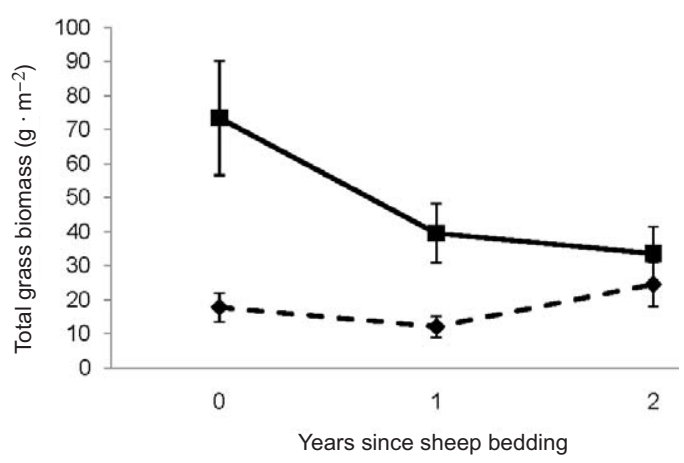

Fig. 5. Change in total grass biomass inside (dashed line) and outside (solid line) historic sheep bedding areas of the U.S. Sheep Experiment Station summer range over time. Error bars represent standard error.

bedding, total plant biomass inside the bedding areas was nearly a third of that outside the bedding areas. Total plant biomass doubled inside the bedding areas the first year after bedding but did not increase outside the bedding areas. In the second year, total biomass declined $20 \%$ inside and outside the bedding areas. At all times, total biomass was less inside the bedding areas than outside.

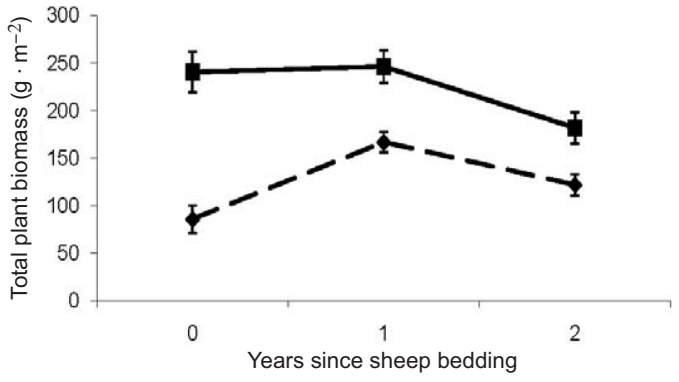

Fig. 6. Change in total plant biomass inside (dashed line) and outside (solid line) historic sheep bedding areas of the U.S. Sheep Experiment Station summer range over time. Error bars represent standard error.

\section{Plant Species}

Four nonnative plant species were identified in this study. Smooth brome (Bromus inermis Leyss.) was identified inside 2 and outside 5 sheep bedding areas. It had $<1 \%$ cover in year 0 and increased to $2.5 \%$ and $6 \%$ in years 1 and 2 , respectively. Smooth brome is widely planted throughout the region and is considered a desirable forage species. Kentucky bluegrass (Poa pratensis L.) consisted of 2-5 plants found in one quadrat outside a bedding area 2 years after bedding. Common dandelion (Taraxacum officinale F. H. Wigg.) consisted of a single plant found in 6 quadrats and was evenly split between inside and outside the bedding areas 1-2 years after bedding, with $<1 \%$ cover. Common dandelion is widespread in the area, and no increased concentration of this species was observed inside the bedding area. Cheatgrass (Bromus tectorum L.) was found in one quadrat inside the bedding area one year after sheep bedding.

Although we were not able to analyze the composition of perennial forb and grass species, it appeared that there were 2 more plant species per plot outside the bedding areas compared to inside the bedding areas. Of all the perennial 
grass and forb species, the only plant species that was more abundant inside (40 sample plots) the bedding areas compared to outside (17 sample plots) was Wyeth biscuitroot (Lomatium ambiguum [Nutt.] J.M. Coult. \& Rose).

\section{DISCUSSION}

\section{Perennial Forb Cover}

Throughout the cycle of grazing and rest, the perennial forb cover was less inside than outside the sheep bedding areas. As perennial forb cover typically accounts for over half the cover in this research area, the reduction in this component makes identification of the boundary of the sheep bedding areas easily discernible. However, the reduction in cover was not reflected in a difference in plant species composition (Appendix), even though there was an expectation that the higher grazing pressure and increased trampling inside the sheep bedding areas would result in a loss of the highly preferred plant species and an increase in grazing and disturbance-tolerant perennial forb species.

\section{Annual Forb Cover}

Sheep bedding areas are classic ruderal sites, sensu Grime (1979), with high levels of disturbance and low levels of environmental stress. The annual forb species that responded positively 1 or 2 years following sheep grazing are native species that possess the characteristics of ruderal plants (Grime 1979). Douglas' knotweed, for example, has been observed to respond rapidly the first year after fire in both mountain big sagebrush (Artemisia tridentata Nutt.) and threetip sagebrush (Artemisia tripartita Rydb.) ecosystems (Harniss and Murray 1973, Seefeldt and McCoy 2003, Seefeldt et al. 2007) and to also respond rapidly to disturbances such as those caused by pocket gophers (Ellison 1946, Ellison and Aldous 1952). Flatspine stickseed populations increased in the second year after bedding, when these sites would be bedded on again. This appearance of flatspine stickseed may be part of a natural selection process, because the plant has a spiny seed that readily attaches to sheep wool, resulting in transport to other bedding areas (Whitson et al. 1996).

\section{Total Forb Cover}

Our measured grazing pressure on annual and perennial forbs highlights sheep preference or forbs during the summer grazing season (Pickford and Reid 1943, Stevens 1966, Laycock et al. 1972, Olson 1999). The increase of grazing pressure and trampling in the sheep bedding areas is reflected in the overall reduction of total forb cover inside compared with outside the sheep bedding areas, and in the temporary reduction of total forb cover inside the bedding areas just after bedding (Fig. 3). On high-elevation Montana rangeland, summer sheep diets were $70 \%$ forbs (Stevens 1966). Similarly, Pickford and Reid (1943) determined that the diets of sheep on subalpine summer range in northeastern Oregon were 66\% forbs, $33 \%$ graminoids, and $1 \%$ browse. In a study that measured the botanical composition of diet using sheep with an esophageal fistula, forbs were $84 \%$ of the diet (Laycock et al. 1972). These summer rangelands provide high-quality forage as evidenced by consistent lamb weight gains from 1 July to 7 September at the USSES summer range. These weight gains averaged $215 \mathrm{~g} \cdot$ day $^{-1}$ over a 4 -year period $(\mathrm{Q}$. Jacobsen personal communication). Although there were some species differences in annual forbs in the first and second year after bedding, there were no differences in the numbers of perennial forb species, and total forb species were the same inside and outside the bedding areas. The forb community in this area seems to be quite resistant to current grazing pressure, unlike the heavily sheep-grazed pastures described near Cedar City, Utah (Ellison 1954, Bowns and Bagley 1986), where a previously forb-dominated range was converted to a grassdominated range. After years of heavy, seasonlong grazing, many of the higher-preference forbs, and those not resistant to grazing pressure, were quite rare compared to their abundance on adjacent cattle-grazed allotments.

\section{Perennial Grass Cover}

Our visual estimation of perennial grass cover was not precise enough to determine differences between inside and outside the sheep bedding areas. Recovery rates of grasses after defoliation correlated with the availability and activity of meristems following defoliation and the interaction of environmental variables and resources (Richards and Caldwell 1985). In this study, the remnant cover of perennial grass was similar inside and outside the bedding area. However, an increase in the number of sheep per unit area combined with the time 
the sheep were inside the bedding areas could have resulted in increased damage to perennial grass meristematic tissues inside compared to outside the bedding areas. At the same time, inside the bedding areas the year after sheep bedding, fertility increased due to the presence of the sheep (Leytem and Seefeldt 2008). This fertility could have increased or decreased perennial plant growth depending on nutrient concentration. The composition of perennial grass species was the same inside and outside the bedding areas.

\section{Shrub Cover}

Shrubs were a minor component inside and outside the sheep bedding areas. There were 6 shrub species measured (Appendix). Sheep will consume brush, especially later in the autumn when other vegetation has senesced (Bork et al. 1998, Snowder et al. 2001). And some brush species, such as sagebrush, have branches that are easily broken when bent, especially when temperatures are below freezing (Seefeldt 2005). The increase in sheep density inside the bedding areas could result in increased opportunities for branch breakage, resulting in decreased brush cover. However, sheep bedding occurred before autumn senescence and freezing temperatures.

\section{Overall Perennial Cover}

Perennial species are the dominant plant cover component in this ecosystem. Long-term sheep bedding has resulted in a decrease in perennial cover inside compared to outside the sheep bedding area. This reduction of cover was not associated with a change in perennial plant species, in contrast to results from research on bomas in Africa (Augustine 2003). In bomas, animals are penned for protection at nights and they will use these pens for an entire grazing season, resulting in considerably more utilization and fertilization than occurred in this study.

\section{Plant Biomass}

Plant biomass inside and outside the bedding areas increased one year after sheep bedding, then declined slightly in the second year. Although plant biomass inside the sheep bedding areas was less than plant biomass outside, the difference between them was less in the first and second years than immediately after sheep bedding. The increase in biomass inside the bedding areas the first year after sheep bedding may be a reflection of the increased annual forb component, and/or it may be due to a response to an increase in nutrients derived from urine and manure that results in larger plants, increased germination, or greater seedling establishment (Leytem and Seefeldt 2008). The second-year decline in biomass was probably an artifact of an earlier sampling date, which occurred well before peak biomass. If biomass samples had been taken at the end of August, then second-year biomass amounts might be equal to, if not greater than, those of the first year.

\section{Plant Species}

Even though the sheep used in this study have exposure to over 20 nonnative plant species during spring grazing on the Upper Snake River Plain, few of these species have seeded before the sheep head to the mountain ranges. In this study, there is no evidence that sheep are spreading nonnative plant species to these high mountain pastures. In the Centennial Mountain range, cheatgrass, Canada thistle (Cirsium arvense [L.] Scop.), leafy spurge (Euphorbia esula L.), and spotted knapweed (Centaurea stoebe L.) are found at these elevations, but typically they occur along roads (improved and unimproved) and railroads.

The recovery of vegetation inside the bedding areas appears to follow a transition that is somewhat similar to transitions occurring in other disturbed ecosystems in the areanamely, a flush of annual forbs followed by growth of vegetation more similar to that of lessdisturbed areas (Seefeldt and McCoy 2003). This research is the first detailed study explicitly examining the impact of sheep bedding on vegetation dynamics; therefore, generalizations are limited, or cannot be made.

\section{Conclusions}

We were able to determine that sheep bedding reduced the quantity of vegetation inside the bedding areas compared to vegetation outside the bedding areas; that there was a differential response of annual forbs and total forbs in the first and second year after bedding inside and outside the sheep bedding areas and among the bedding areas; and that these bedding sites were not invaded by nonindigenous plant species. After 2 years, there remained a difference in vegetation biomass inside the 
bedding areas compared to outside the areas. There was an increase in annual forb cover and biomass inside the bedding areas the first year after sheep bedding, and an increase in total forb cover the first year after sheep bedding. However, it appears that, although sheep bedding reduces vegetation quantity and changes the relative abundance of annual forbs, it does not result in nonnative plant invasions. It appears that long-term use of these sites as sheep bedding areas in this ecosystem is not significantly degrading the vegetation.

\section{ACKNOWLEDGMENTS}

We express our appreciation to Quinn Jacobsen, Ada Williamson, Boyd Leonard, Lindsy Balis, Pernecia Heinemann, and Seth Oliver for their technical assistance. The use of trade, firm, or corporation names in this publication is for the information and convenience of the reader. Such use does not constitute an official endorsement or approval by the USDA or the authors and does not imply its approval to the exclusion of any product or service to the exclusion of others that may be suitable.

At the time research was conducted, the senior author was Rangeland Scientist, U.S. Department of Agriculture, Agricultural Research Service, U.S. Sheep Experiment Station, Dubois, ID 83543.

\section{Literature Cited}

ANONYMOUS. 1999. Climatological data annual summary Idaho. National Oceanic and Atmospheric Administration Report V102, \#13.

Augustine, D.J. 2003. Long-term, livestock-mediated redistribution of nitrogen and phosphorus in an East African savanna. Journal of Applied Ecology 40:137-149.

Bork, E.W., N.E. West, And J.W. WALKer. 1998. Cover components on long-term seasonal sheep grazing treatments in three-tip sagebrush steppe. Journal of Range Management 51:293-300.

Bowns, J.E. 1971. Sheep behavior under unherded conditions on mountain summer ranges. Journal of Range Management 24:105-109.

Bowns, J.E., AND C.F. BAGLEy. 1986. Vegetation responses to long-term sheep grazing on mountain ranges. Journal of Range Management 39:431-434.

Buchanan, H., W.A. LayCoCK, AND D.A. PRICE. 1972 Botanical and nutritive content of the summer diet of sheep on a tall forb range in southwestern Montana. Journal of Animal Science 35:423-430.

Craddock, G.W., and C.L. Forsling. 1938. The influence of climate and grazing on spring-fall sheep range in southern Idaho. Technical Bulletin No. 600, United States Department of Agriculture, Washington, DC.
ELLISON, L. 1946. The pocket gopher in relation to soil erosion on mountain range. Ecology 27:101-114.

1954. Subalpine vegetation of the Wasatch Plateau, Utah. Ecological Monographs 24:80-184.

Ellison, L., AND C.M. Aldous. 1952. Influence of pocket gophers on vegetation of subalpine grassland in central Utah. Ecology 33:177-186.

Grime, J.P. 1979. Plant strategies and vegetation processes. John Wiley \& Sons, New York, NY. 222 pp.

HaRniss, R.O., AND R.B. MurRaY. 1973. 30 years of vegetal change following burning of sagebrush-grass range. Journal of Range Management 26:322-325.

KNIGHT, D.H. 1994. Mountains and plains: the ecology of Wyoming landscapes. Yale University Press, New Haven, CT. 338 pp.

Lavorel, S., K. Grigulis, S. McIntyre, N.S.G. Williams, D. Garden, J. Dorrough, S. Berman, F. Quétier, A. Thébault, and A. Bonis. 2008. Assessing functional diversity in the field - methodology matters! Functional Ecology 22:134-147.

Laycock, W.A., H. Buchanan, AND W.C. Krueger. 1972. Three methods of determining diet, utilization, and trampling damage on sheep ranges. Journal of Range Management 25:352-356.

Leytem, A.B., And S.S. SEefEldt. 2008. Impact of sheep bedding on soil nutrient dynamics in the Centennial Mountains of Montana and Idaho. Soil Science 173: 503-510.

Olson, B.E. 1999. Grazing and weeds. Pages 85-96 in R.L. Sheley and J.K. Petroff, editors, Biology and management of noxious rangeland weeds. Oregon State University Press, Corvallis, OR.

PICKFoRD, G.D., AND E.H. REID. 1943. Competition of elk and domestic livestock for summer range forage. Journal of Wildlife Management 7:328-332.

REID, R.S., AND J.E. ELLIS. 1995. Impacts of pastoralists on woodlands in South Turkana, Kenya: livestockmediated tree recruitment. Ecological Applications 5:978-992.

Richards, J.H., And M.M. Caldwell. 1985. Soluble carbohydrates, concurrent photosynthesis and efficiency in regrowth following defoliation: a field study with Agropyron species. Journal of Applied Ecology 22:907-920.

Scimone, M., A.J. Rook, J.P. Garel, AND N. Sahin. 2007. Effects of livestock breed and grazing intensity on grazing systems: 3. Effects on diversity of vegetation. Grass and Forage Science 62:172-184.

SEefELDT, S.S. 2005. Consequences of selecting Rambouillet ewes for mountain big sagebrush (Artemisia tridentata spp. vaseyana) dietary preference. Rangeland Ecology and Management 58:380-384.

Seefeldt, S.S, M. Germino, and K. DiCristina. 2007. Prescribed fires in Artemisia tridentata ssp. vaseyana steppe have minor and transient effects on vegetation cover and composition. Applied Vegetation Science 10:249-256.

SEEFELDT, S.S., AND S.D. McCoy. 2003. Measuring plant diversity in the tall threetip sagebrush steppe: influence of previous grazing management practices. Environmental Management 32:234-245.

SNOWder, G.D., J.W. Walker, K.L. Launchbaugh, and L.D. VAN VLECK. 2001. Genetic and phenotypic parameters for dietary selection of mountain big sagebrush (Artemisia tridentata Nutt. spp. vaseyana [Rydb] Beetle) in Rambouillet sheep. Journal of Animal Science 79:486-492. 
StelFox, J.B. 1986. Effects of livestock enclosures (bomas) on the vegetation of the Athi Plains, Kenya. African Journal of Ecology 24:41-45.

Stevens, D.R. 1966. Range relationships of elk and livestock, Crow Creek drainage, Montana. Journal of Wildlife Management 30:349-363.

Whitson, T.D. [editor], L.C. Burrill, S.A. Dewey, D.W. Cudney, B.E. Nelson, R.D. Lee, and R. Parker. 1996. Weeds of the West. Western Society of Weed Science in cooperation with Cooperative Extension
Services, University of Wyoming, Laramie, WY. 630 pp.

Youngblood, A.P., W.G. Padgett, and A.H. WinWard. 1985. Riparian community type classification of east ern Idaho-western Wyoming. R4-Ecol-85-01, USDA Forest Service, Intermountain Region, Ogden, UT. $78 \mathrm{pp}$.

Received 25 January 2010 Accepted 12 April 2011

Appendix on pages 371-373. 


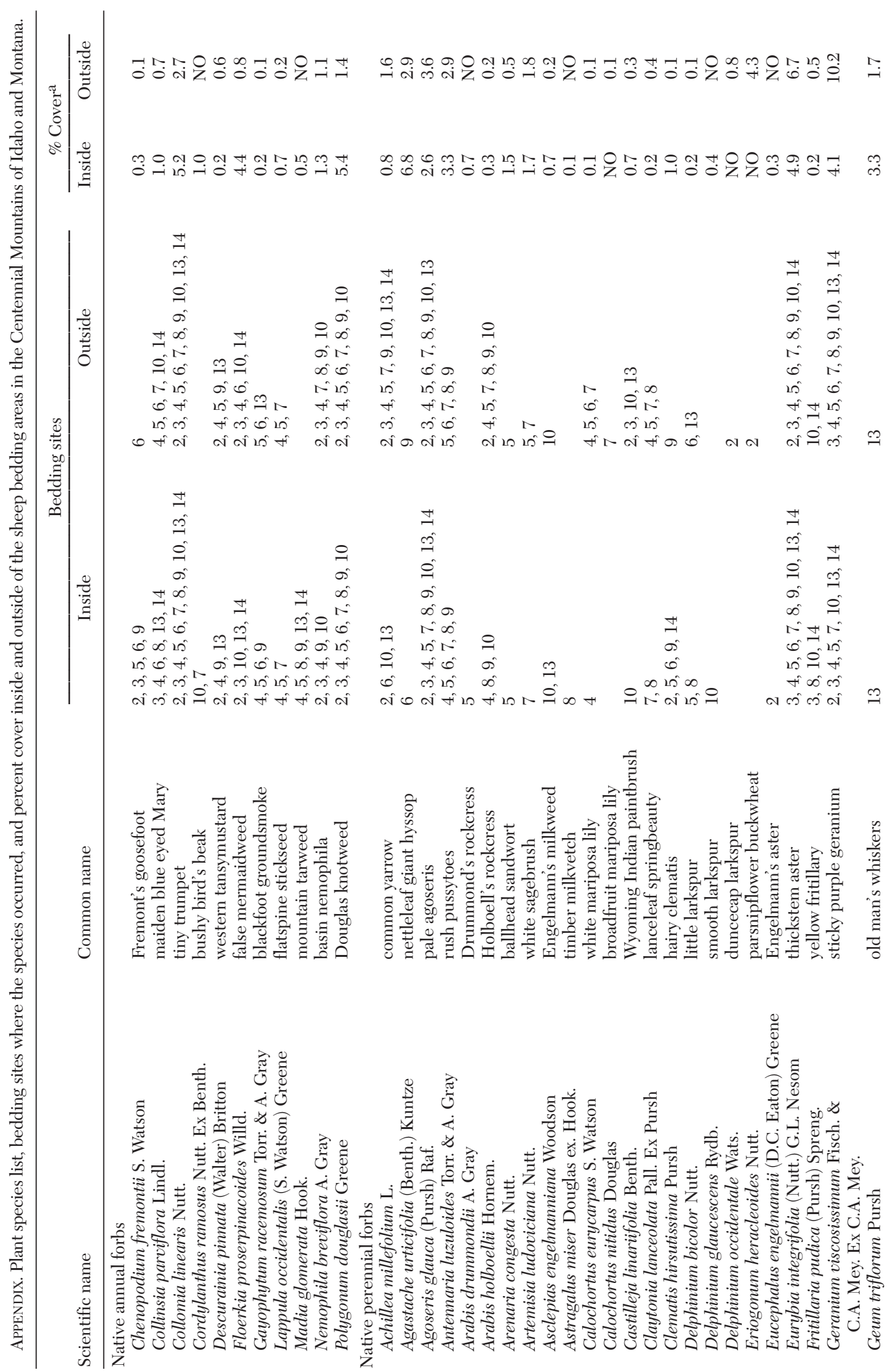




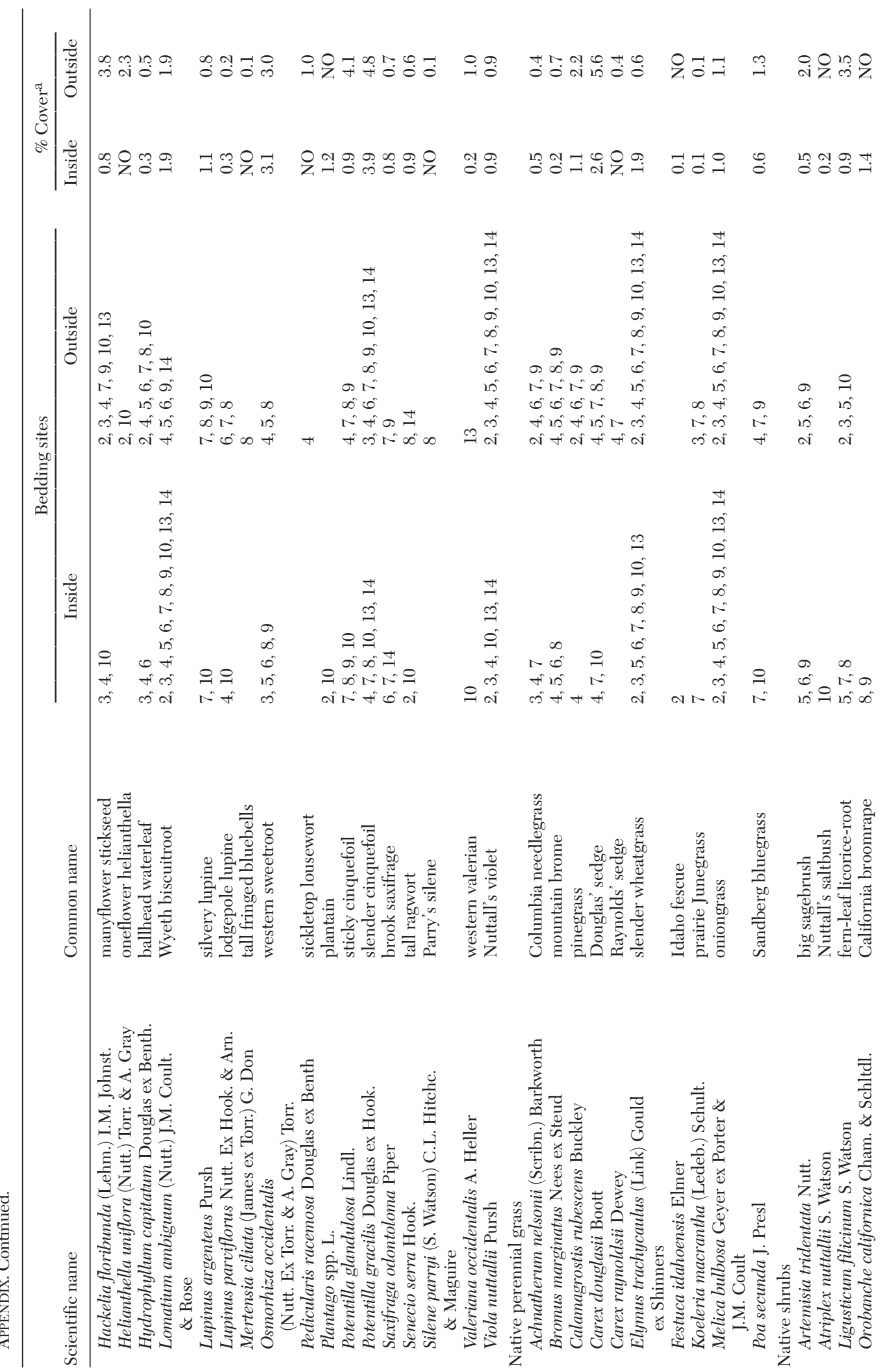




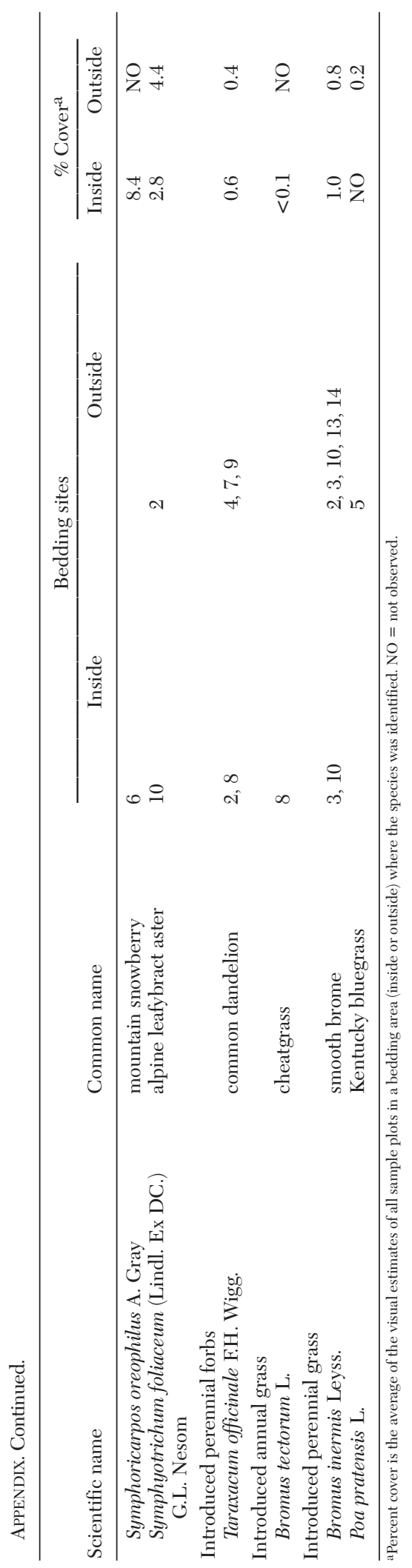

